\title{
Enterprise Receivables Management
}

\author{
Svetlana Firsova *, Galina Onchukova \\ Economic Engineering Faculty, Kalashnikov lzhevsk State Technical University, Department of Finance and Credit, Izhevsk, Russia
}

\begin{abstract}
In the market economy conditions there are practically no economic entities which carry out their business without accounts receivable. This being said, the market for the goods (work, services) is expanding for the creditor and for the debtor it becomes possible to attract additional financial resources. The causes of the accounts receivable occurrence are determined both macro-level factors and internal factors of the enterprise. Accounts receivable is the most dynamic element of enterprise current assets and its amount and dynamics depend on the effectiveness of the current credit policy. Receivables management is one of the most important tasks of the current operations of the financial manager. The turnover, profitability of current assets, financial stability, competitive edge and financial standing of the enterprise largely depend on the receivables management. The article discusses some questions connected with definition, necessity of receivables management, its classification, formation of the system approach and algorithm of the effective management.
\end{abstract}

Keywords: accounts receivable; credit policy of the enterprise; system approach; management; effectiveness.

\section{Introduction}

In today's economic environment, enterprises face the lack of funds to finance their activities, with that the majority of them has a high proportion of the accounts receivable in the structure of current assets.

According to the Federal State Statistics Service (Rosstat), in Russia the share of current assets advanced to accounts receivable in 2015 ranged from 14.2\% to 49.9\%, depending on the branch of the economy [1].

When shipping products, money, as a rule, does not arrive at the settlement account immediately but is only formed, disclosing in the accounting statements. The period from the moment of shipment of the products to the moment of receipt of payment is a period, during which the funds are "frozen" in the form of accounts receivable. This money cannot be used by the enterprise in its own interests, for example, to purchase materials, pay off with creditors and borrowers. All these can negatively affect the enterprises' operations, reducing financial stability, solvency and profitability of capital.

The importance of this subject is also defined by the fact that the enterprises often face the problem of non-repayment of accounts receivable. Lack of funds can lead to a financial resources deficit, a breach of time limits for payments with suppliers, an attraction of the additional credits at high interest rates and an elongation of the tax payments due date. Rational receivables management and the development of the appropriate algorithm will allow to achieve the necessary level of profitability and to decrease overdue liabilities.

\section{Experimental Section}

In scientific literature, there are different approaches to the subject matter of the accounts receivable. On a point of law, in accordance with the Civil Code of the 
Russian Federation, accounts receivable represent the duty of the debtor to the creditor when providing him goods (work, services) and refer to objects of civil rights - property rights [2].

From the accounting perspective, accounts receivable is the part of the enterprises' assets and must comply with the certain conditions which are necessary to include it in the asset: to make profits in the future; to be at the disposal of an economic entity that can use it at its own discretion or sell it; to be the result of earlier transactions.

In marketing, accounts receivable is a tool for stimulating demand or a commodity credit, which is provided by the firm to its customers.

The accounts receivable treatment in corporate finance as a form of capital investment is defined as follows: granting a deferred payment for the products sold and lending to its debtors, allowing the company to reckon on the additional volume of sales and profits in the future $[4,3]$.

In accordance with the International Financial Reporting Standards (IFRS), IAS 32 - "Financial Instruments: Presentation of Information", accounts receivable are financial assets which represent financial claims that give their holder the right to receive payment, that is, the contractual right to claim for funds or for other financial assets from another company $[3,4]$.

The variety of approaches to the definition of accounts receivable indicates its impact on different aspects of the enterprise operations.

As of today, the majority of the companies for planning, evaluation and collection of accounts receivable use only limited number of methods that solve only part of the receivables management problems. At a number of enterprises there is no well-defined system of customers lending. The analysis of the debt turnover, as a rule, is either not carried out, or carried out on the enterprise as a whole, which ultimately leads to erosion of the overdue debts in the total amount of debt, misrepresenting the actual situation. All the aforesaid determines the need to solve the problem of regulating accounts receivable to identify overdue debts and take the necessary measures to optimize its amount and debt.

There are different points of view with regard to the content of receivables management. Summarizing the variety of approaches, management of accounts receivable can be presented as a part of effective enterprise management aimed at increasing the profit from sales of products by optimizing the amount of accounts receivable and its collection by the due date, optimizing the company's cash flow while minimizing the costs associated with its management in a certain period.

Since the receivables management is a part of the enterprise management system that is actualized in the course of time, the process itself can be identified by successive stages, which form the algorithm for the effective receivables management:

- Formation of the purposes of receivable management, corresponding to a financial policy within the framework of corporate policy of development of the enterprises as a whole;

Identification of accounts receivable types and their classification;

Determination of factors affecting the level of accounts receivable, calculation of the corresponding indicators;

- Selection of methods and tools for receivables management;

- Definition of the credit policy parameters;

- Monitoring and control of results at every stage of receivables management and their adjustment;

- Motivation of receivables management managers.

In the context of effective management, such an algorithm for receivables management includes all the main interrelated management functions: planning, organization, motivation and control.

The objectives of receivables management have to be formed in the long-term and short-term periods. In the long-term period, the goal is to increase the market value of the enterprise's capital through maximizing the aggregate cash flow with minimal costs of debt formation. In the short-term period, the goals are determined by the situation in the enterprise. These goals can be: the decrease in overdue debts of past periods; optimization of the accounts receivable amount on the volume and terms of lending to customers; minimization of the debt position for each counterparty.

\section{Results and Discussion}

The variety of approaches to defining the accounts receivable subject matter determines the need for its classification.

A review of the specialized literature and practice of receivables management at industrial enterprises in Russia made it possible to identify 
Tab. 1: Classification of Accounts Receivable.

\begin{tabular}{|c|c|c|}
\hline Criterion of Classification & Goal & Classification groups \\
\hline $\begin{array}{l}\text { Composition of accounts } \\
\text { receivable }\end{array}$ & \multirow[t]{2}{*}{$\begin{array}{l}\text { Accounting for the purpose of preparation } \\
\text { of financial statements; development of cre- } \\
\text { dit policy }\end{array}$} & $\begin{array}{l}\text { Receivable from customers } \\
\text { Bills receivable } \\
\text { Receivable of subsidiaries and affiliates } \\
\text { Receivable of founders by contributions } \\
\text { to the equity capital } \\
\text { Advances made } \\
\text { Sundry debtors }\end{array}$ \\
\hline Age of receivable & & $\begin{array}{l}\text { Short-term (payments are expected wi- } \\
\text { thin } 12 \text { months after the reporting date) } \\
\text { Long-term (payment period exceeds } 12 \\
\text { months after the reporting date) }\end{array}$ \\
\hline Quality of receivable & $\begin{array}{l}\text { Control over accuracy of payment and re- } \\
\text { fund; assessment of the impact on finan- } \\
\text { cial results }\end{array}$ & $\begin{array}{l}\text { Current } \\
\text { Overdue: } \\
\boldsymbol{v} \text { doubtful; } \\
\boldsymbol{\checkmark} \text { uncollectible. }\end{array}$ \\
\hline $\begin{array}{l}\text { Types of the enterprises' } \\
\text { operations }\end{array}$ & $\begin{array}{l}\text { Selecting a method for receivables mana- } \\
\text { gement }\end{array}$ & $\begin{array}{l}\text { Commercial } \\
\text { Noncommercial }\end{array}$ \\
\hline
\end{tabular}

the factors that affect its level and determine the indicators characterizing them. These factors have a multifaceted impact on the enterprise operations, depend on the specifics of business and industry (product type and demand for it, market capacity, accounting system, etc.) and can be classified according to the following characteristics: quantitative, qualitative, temporal, degree of influence on the financial condition of the enterprise (interdependence, uncertainty, financial stability and production potential).

The influence of quantitative factors can be calculated through the following indicators: the share of accounts receivable in assets, in current assets, in sales proceeds. The qualitative aspect is realized through such indicators as the share of doubtful and overdue receivables in the total amount of debt, repayment rates and collection of accounts receivable, the ratio of receivables and payables. The temporal aspect can be characterized through the period of turnover of accounts receivable and payable, the operational and financial cycle of the enterprise.

Degree of interdependence of accounts receivable and financial condition can be estimated by following indicators: profitability of sales, profitability of production and profitability of a cash flow. The degree of uncertainty can be calculated through an estimation of the probability of receivables collection. The degree of financial stability - through following indicators: current, quick, absolute liquidity ratio, solvency recovery ratio and the coefficient of the economic security of its own current assets. The level of production potential involves the calculation of the enterprise's asset profile coefficient.

Selection of methods and tools for receivables management implies a toolkit that will be used for direct receivables management. The variety of such methods and tools is widely represented in the modern financial literature:

\section{- Careful analysis of accounts receivable in the previous period;}

- Compiling a register of aging accounts receivable, which is based on the distribution of each debtor by the time of occurrence;

- Formation of collection methods and tools, which include the analysis of the solvency of a particular client, the method of assigning a creditrating, discount rate calculations, sending notification letters and phone calls to customers;

- Formation of methods and tools of refinancing, including factoring, bills discounting, forfaiting.

The definition of the credit policy parameters is an important stage of the algorithm, because on the basis of complete information on the state of the receivables, the enterprise forms and further adjusts the chosen type of credit policy with respect to the creditor. The scope of work on creating a credit policy involves the development of standards for the creditworthiness of customers, the establishment 
of terms for the provision of loans, the creation of conditions and amounts for the granting of discounts and fines, and the creation of a reserve for doubtful receivables.

There are different types of credit policy: conservative, moderate and aggressive. When determining the type of credit policy, one should take into account that the conservative type negatively affects the volume of sales, while the aggressive type can promote the diversion of financial resources from the turnover of the enterprise, increase the costs of collecting receivables, thereby reducing the profitability of its operations.

Monitoring of the results of receivables management is the final stage of the whole algorithm. This stage acts as an automatic regulator, providing control over the state of receivables. As quantitative standards, it is necessary to develop a system of financial standards. At this stage, the assessment of the resulting deviations is analyzed and evaluated, and, ultimately, the level of the receivables is regulated with a view to further adjustment. Also, it is important to take into account that the monitoring of results should be carried out at each stage of the algorithm to provide a more efficient system for receivables management.

The motivation of receivables management managers is characterized by the appropriate stimulation of employees of enterprise unit structures. For example, the units that provided the largest amount of revenue with the minimal delay in payment receive a financial incentive.

\section{Conclusions}

Thus, we can conclude that the receivables management is a part of the effective management of the enterprise. Receivables management should be based on a competent management algorithm with clearly defined, interrelated stages. The creation of such a system will allow the enterprise to monitor the state of settlements with customers, reduce the risk of accounts receivable non-payment, develop an optimal policy for granting installment payments, which ultimately lead to an improvement in the financial condition and growth of the market value of the enterprise's capital.

\section{References}

[1] Rosstat. Finance of Russia, from http://www.gks.ru/ free_doc/doc_2016/fin16.pdf, p. 116-117, (date of access:
24.04.2017).

[2] No. 51-FZ (article 128), November 30, 1994 (as amended on March 28, 2017). Civil Code of the Russian Federation (Part One)".

[3] Brighem U., Gapenski L. (1997) Financial management. Full course. Economical School, Saint-Petersburg, p. 316; 5, p. 367; 6, p. 584-585.

[4] International Financial Reporting Standards (IFRS), IAS 32 "Financial Instruments: Presentation of Information", from http://minfin.ru/ru/document/?id_4=15323 (date of access: 24.04.2017).

[5] Romanovsky M.V., Vostroknutova A.I. (2014). Corporate Finance: A Textbook for Universities. Piter, Saint-Petersburg

[6] Ross S. (2000) Fundamentals of corporate finance. Laboratory of Basic Knowledge, Moscow.

\section{Biographical notes}

Svetlana Firsova: PhD in Economics, (born in 1970) is an Associate Professor at the Kalashnikov State Technical University, Economic Engineering Faculty, Finance and Credit Department. She received a Master's Degree in Finance at Volodymyr Dahl East Ukrainian National University in 2003. In 2013 she defended her thesis and obtained a Ph.D. in Economics (Economics and Enterprise Management), Ukraine. Her scientific interests include management of enterprises by types of economic activity; marketing. She is a coordinator of cooperation with technical universities of Ukraine and CIS countries; Curator of the direction "Banking" of the Institute of Continuing Vocational Education. Her most relevant publication outputs are "Manufacturing Company and Its Communication", "The process of integrated marketing communication", "Strategic controlling of innovation activities of enterprises in the changing technological structure of economy".

Galina Onchukova: PhD in Economics, (born in 1958) is an Associate Professor at the Kalashnikov State Technical University, Economic Engineering Faculty, Finance and Credit Department. She graduated from the Faculty of Economics and organization of the machine-building industry in 1980. Her research areas are corporate finance, state and municipal finance. She is the Head of the Master's educational program "Finance", "Finance and credit". Her most relevant publication outputs are "Problems of Execution of Tax and Non-Tax Revenues of Budgets of Municipal Formations in Modern Economic Conditions (as exemplified by the MO "Izhevsk (ity")", "Analysis of domestic approaches in the formation of the company's financial strategy", "Management of the process of reproduction of fixed assets of gas distribution organizations". 